\title{
EPIDEMIOLOGY AND CONTROL OF LEAF AND AWN SPOT OF BARLEY CAUSED BY RAMULARIA COLLO-CYGNI
}

\section{I.C. HARVEY}

\author{
PLANTwise Services, PO Box 8915, Christchurch \\ Corresponding author: harveyi@plantwise.co.nz
}

\begin{abstract}
Leaf and awn spot of barley, caused by the fungus Ramularia collo-cygni (=Ovularia hordei) has been prevalent in crops in Canterbury, New Zealand, over the last few seasons, causing rapid leaf senescence late in the season. Control can readily be achieved with a single triazole and strobilurin fungicide application, but timing of application at late booting is important. A rate response to a triazole fungicide was noted but there was no response to the rates of the strobilurin fungicides tested. Good control is achieved at both high and low application rates with strobilurins. The correlation between disease severity and grain yield shows a nonlinear relationship, with low levels of disease having a major influence on grain yield. Seed infection has also been noted, but the significance has not been evaluated.

Keywords: Barley disease, leaf and awn spot, Ramularia collo-cygni, disease control, seed infection.
\end{abstract}

\section{INTRODUCTION}

A leaf, leaf sheath and awn spot of barley was recorded in New Zealand in 1983 concurrently in both the North (N. Grbavac, pers. comm.) and South Islands (I.C. Harvey, unpubl. data). It was diagnosed as being caused by the fungal pathogen Ovularia hordei (Cav.) Sprague. The common name given to the disease was Ovularia leaf spot of barley (Harvey 1986). The disease, characterised by the rapid appearance of small, brown spots on leaves, sheaths and awns late in the season, causes rapid loss of green leaf area. The disease was often mistaken for physiological blotch of barley, which sometimes causes similar spotting but not rapid loss of green leaf area.

Sutton \& Waller (1988) changed the Latin binomial for the fungal pathogen to Ramularia collo-cygni and the disease became known in the Northern Hemisphere as Ramularia leaf and awn spot of barley. The difference in common names between New Zealand and Europe has caused some confusion. The pathogen has historically also been referred to as Ophiocladium hordei Cavara and erroneously synonymised with Ovularia pusilla (Sprague 1955), the cause of a common leaf spot of ryegrass in New Zealand (Latch 1964).

The disease was anecdotally recorded as being controlled by triazole fungicides (Harvey 1986, 1998), but there were no reliable records of the effects that the disease had on final grain yield. This paper reports on the variation in severity of the disease over the last three seasons in Canterbury, and presents some observations on disease development and the effects of fungicides on the control of the disease and subsequent grain yield.

\section{METHODS}

This paper presents results from five trials that were all were managed and assessed for disease in a similar manner. The 1998-99 trial was in Temuka, South Canterbury on the property of G. Talbot in a crop of Optic barley sown 15 October 1998.

The 1999-2000 trial was on the property of D. Grant, Methven, within a crop of Optic barley sown 3 September. Fungicides (see Table 1) were applied on 4 December 1999 on $9 \mathrm{~m} \times 3 \mathrm{~m}$ plots in a four replicate randomised block design.

New Zealand Plant Protection 55:331-335 (2002) 
The 2000-2001 trial was on the property of J. Mulholland, Greendale, Canterbury, in a crop of Dash barley, sown 3 August 2000.

The two 2001-2002 barley trials were on the properties of J. Mulholland in Greendale sown 17 September 2001 (cv. Dash) and Q. Withell in Irwell sown 14 October 2001 (cv. Optic), both in Canterbury.

TABLE 1: The fungicides and rates of application used in the 1999-2000 trial.

\begin{tabular}{|c|c|c|c|c|c|}
\hline Product & Group & Supplier & Chemical & $\begin{array}{l}\mathrm{ml} \text { or } \mathrm{g} \\
\text { ai/litre }\end{array}$ & $\begin{array}{c}\mathrm{ml} \text { or } \mathrm{g} \\
\text { product/ha }\end{array}$ \\
\hline Folicur & triazole & Bayer (NZ) & tebuconazole & 250 & 440 \\
\hline Opus & triazole & BASF (NZ) & epoxiconazole & 125 & 1000 \\
\hline Amistar & strobilurin & Crop Care (NZ) & azoxystrobin & 250 & 750 \\
\hline Allegro & $\begin{array}{l}\text { strobilurin } \\
+ \text { triazole }\end{array}$ & BASF (NZ) & $\begin{array}{l}\text { kresoxim-methyl } \\
+ \text { epoxiconazole }\end{array}$ & $\begin{array}{r}125 \\
+125\end{array}$ & 1000 \\
\hline Protek & benzimidazole & Taranaki NuChem & carbendazim & 500 & 500 \\
\hline
\end{tabular}

In the 1999-2000 trial, three disease assessments were carried out from the time of fungicide application to 20 January 2000 . Ten representative main stems from throughout each plot were sampled and taken to the laboratory for examination. The percentage leaf area affected by the disease and green leaf area was determined using standard leaf area diagrams (James 1971) on leaf 2 and 3 down the plant. Harvest was on 24 February 2000 , using a Wintersteiger "Elite" plot combine by taking a $1.7 \mathrm{~m}$ swath through the middle of each plot. Statistical analysis on the data was by ANOVA, from which LSDs (least significant differences) were calculated at the $95 \%$ confidence levels.

\section{RESULTS AND DISCUSSION}

From the five trials over the four years of assessment, there has been a variation in the severity of leaf and awn spot of barley in untreated trial plots in Canterbury (Table 2). Results are given for the penultimate leaf (flag leaf -1 ), and assessments were all made as leaf senescence was well advanced, but not complete.

TABLE 2: The severity of Ramularia leaf and awn spot of barley on penultimate leaves over four seasons, five trials and two cultivars. Data are for untreated plots.

\begin{tabular}{llllr}
\hline Season & Cultivar & Location & Assessment date & \% leaf area affected \\
\hline $1998-1999$ & Optic & Temuka & 22 January & 9.1 \\
$1999-2000$ & Optic & Methven & 21 January & 18.8 \\
$2000-2001$ & Dash & Greendale & 30 December & 7.7 \\
$2001-2002$ & Dash & Greendale & 4 January & 0.0 \\
$2001-2002$ & Optic & Irwell & 14 February & 9.4
\end{tabular}

These are typical assessment results over the last four seasons, and show that the disease varied in severity from year to year. In the 2001-2002 season, there was little disease in crops that were sown in September, but later sown crops (i.e. in October) did develop the disease to an extent that affected final yield.

Since Ramularia leaf and awn spot was at its highest in the 1999-2000 season, results from this trial are reported. There were only traces of other common barley foliage diseases in this trial. When applied at label rates, all fungicides gave significant control of the 
disease $(\mathrm{P}<0.05)$, but best control was by Opus, Allegro and Amistar (Fig. 1). Opus was significantly better than Folicur, which was better than Protek. However, there was no difference in control between Opus, Allegro and Amistar when applied at the label rate.

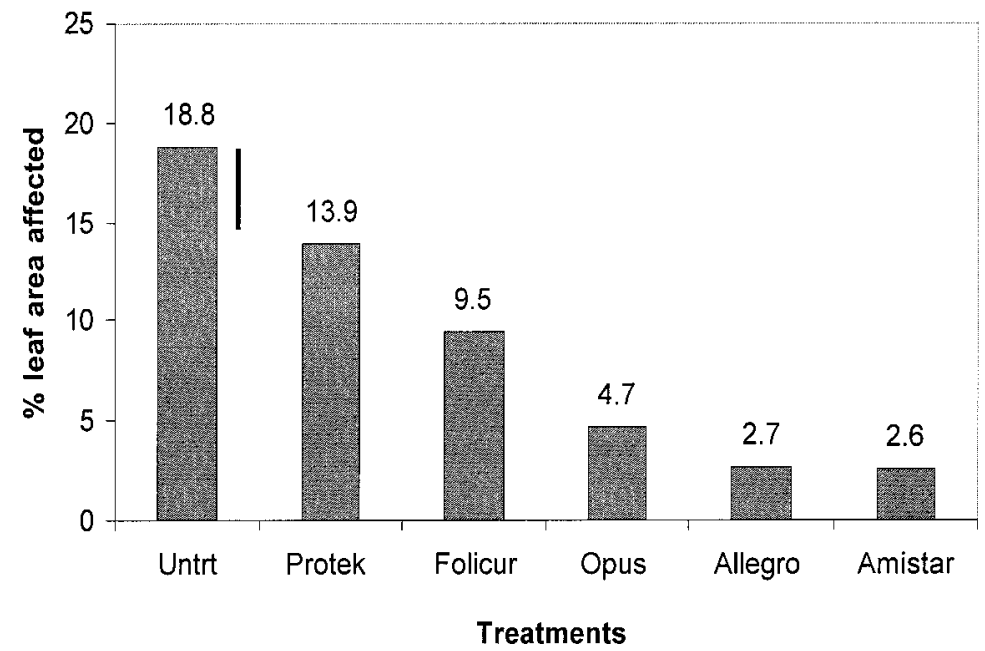

FIGURE 1: The severity of Ramularia leaf and awn spot of barley on penultimate leaves of main stems, assessed 47 days after treatment with five fungicides applied at label rates in the 1999-2000 trial. Bar $=4.2$ (LSD P<0.05).

In the 1999-2000 trial, the above fungicides were applied at a range of variations from label rates (Table 3). The triazole fungicide Opus gave an increase in control response with increases in chemical concentration, whereas the two fungicides containing strobilurins (Amistar and Allegro) gave very good and non-significantly different levels of control at all rates of application that were tested. Control responses to lower application rates of strobilurins require further investigation. The triazole Folicur gave no difference in control at either half or full rates of application.

TABLE 3: The severity of Ramularia leaf and awn spot on penultimate leaves of main barley stems $\mathbf{4 7}$ days after treatment with four fungicides at different application rates in the 1999-2000 trial. The nil treatment had $18.8 \%$ leaf area affected.

\begin{tabular}{|c|c|c|c|c|}
\hline \multirow{2}{*}{$\begin{array}{l}\text { Variation from } \\
\text { label rate }\end{array}$} & \multicolumn{4}{|c|}{$\%$ leaf area affected } \\
\hline & Opus & Folicur & Amistar & Allegro \\
\hline 0.25 & 12.5 & & & \\
\hline 0.5 & 8.4 & 10.5 & & 3.7 \\
\hline 0.75 & 5.8 & & 2.5 & 1.8 \\
\hline 1.0 & 4.7 & 9.5 & 2.6 & 2.7 \\
\hline 1.25 & 3.8 & & 2.0 & \\
\hline 1.5 & & & & 1.3 \\
\hline 2.0 & & & 2.2 & \\
\hline LSD $(\mathrm{P}<0.05)$ & & & & \\
\hline
\end{tabular}


Results of green leaf area assessments taken 47 days after assessment and final grain yield were compared to the assessment scores for Ramularia leaf and awn spot as outlined in Table 3. The correlation coefficients were as follows:
Between green leaf area and Ramularia:
Between green leaf area and yield:
$r=-0.71$
Between Ramularia and yield:
$\mathrm{r}=0.84$
$r=-0.83$

When final grain yield was compared with the severity of Ramularia leaf and awn spot at the time of leaf senescence, the relationship was found to be non-linear (Fig. 2). This suggests that even at low levels of infection, the disease has a marked effect on the grain yield in barley. This is probably due to the observation that the disease affects the onset of leaf senescence.

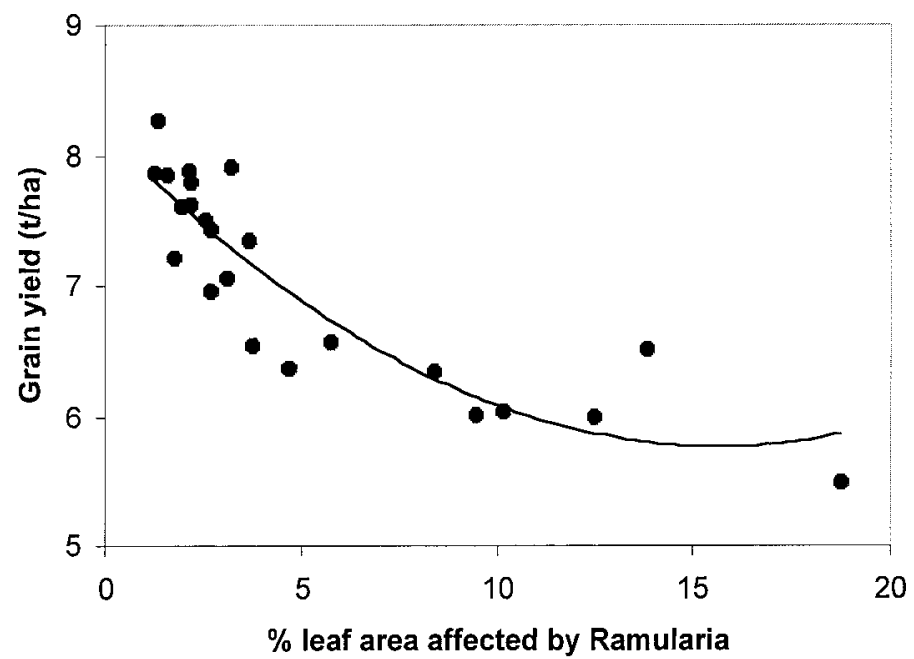

FIGURE 2: The relationship between final grain yield in barley and severity of Ramularia leaf and awn spot in the 1999-2000 trial.

In the 2001-2002 harvest a crop with heavy Ramularia infection was found to have approximately $10 \%$ of seeds infected, with the pathogen sporulating along the shoulders of the ventral crease. This is the first report of the fungus being observed on seed.

Ramularia leaf and awn spot is not recorded as a serious disease in most barley growing countries (see Mather 1997), although it has become more prevalent in the last twenty years in New Zealand and recently in Europe and Great Britain (E. Sachs, Kleinmachnow, Germany, pers. comm.).

There is much debate about the aetiology of the disease (S. Oxley, Edinburgh, UK, pers. comm.). In barley crops that have been observed in Canterbury over the last four seasons, the disease has usually appeared on upper leaves late in the season, with no sign of infection on lower leaves at earlier developmental stages of the crop. However, in the 2001-2002 season, symptoms were observed on lower leaves on late sown barley crops well before grain filling. This suggests that the disease may be in the crop earlier in other seasons but is not being expressed because either the prevailing weather conditions are unfavourable or the infection is latent and is not expressed until a certain developmental stage in the crop is reached. In the 2001 - 2002 season, there was little disease in the trial plots set up in crops sown in September. However, in the later sown 
crops (i.e. in October) the disease did develop to an extent that affected final yield (I. Harvey, unpubl. data).

\section{CONCLUSIONS}

The results presented in this paper highlight the varying nature of Ramularia leaf and awn spot of barley from season to season in Canterbury and confirm that it has a marked effect on grain yield. The observation of Ramularia infection on barley seed and the developmental aspects of the disease require further investigation under New Zealand conditions.

\section{ACKNOWLEDGEMENTS}

Thanks to the Foundation for Arable Research for the funding of the trials referred to in this paper; Bede McCloy of New Zealand Arable and Matthew Hicks of Cropmark Seeds for their management of the trials; and Sophie Walker, Bronwyn Braithwaite, John Hayman, Alan Uprichard and Keith Dunlop for assistance with sample collection and disease assessments.

\section{REFERENCES}

Harvey, I.C. 1986: Ovularia leaf spot. In: Cereals - Minor Diseases and Disorders. MAF Information Aglink FPP 841.

Harvey, I.C. 1998: Ovularia Leaf Spot of Barley. FAR Disease Profile. In: FAR (Foundation for Arable Research) Lincoln, Infobase CD.

James, C. 1971: Assessment keys for plant diseases. Can. Plant Disease Survey 51(2): 39-65.

Latch, G.C.M. 1964: Ramularia pusilla Ung. and Ramulaspera holci-lanati (Cav.) Lind. in New Zealand. N.Z. J. Agric. Res 7: 405-416.

Mather, D.E. 1997: Compendium of Barley Diseases. Second Edition. APS., St Paul, Minnisota, USA. 90 p.

Sprague, R. 1955: Some leaf spot fungi of Western Gramineae. IX. Mycologia 47: 835845.

Sutton, B.C.; Waller, J.M. 1988: Taxonomy of Ophiocladium hordei, causing leaf lesions on Triticale and other gramineae. Trans. Brit. Mycol. Soc. 90 (1): 55-61. 